\title{
SOCIOECONOMIC DRIVERS OF SPATIO-TEMPORAL LAND USE/LAND COVER CHANGES IN A RAPIDLY URBANIZING AREA OF CHINA, THE SU-XI-CHANG REGION
}

\author{
YIRSAW, E. ${ }^{1,2}-\mathrm{WU}, \mathrm{W} .{ }^{1,3^{*}}-$ TEMESGEN, H. ${ }^{1,4}$ - BEKELE, B. ${ }^{1,5}$ \\ ${ }^{I}$ Nanjing Agricultural University, College of Land Management, Nanjing 210095, China \\ (e-mail: eshetu.yirsaw@yahoo.com) \\ ${ }^{2}$ Alage ATVET College, Department of Natural Resources Management, Alage, Ethiopia \\ ${ }^{3}$ National and Joint Local Engineering, Research Center for Rural Land Resources Use and \\ Consolidation, Nanjing 210095, China \\ (e-mail:ww@njau.edu.cn) \\ ${ }^{4}$ Dilla University, Department of Land Resources Management, Dilla, Ethiopia \\ (e-mail: habte023@yahoo.com) \\ ${ }^{5}$ Assosa ATVET College, Department of Natural Resources Management, Assosa, Ethiopia \\ (e-mail: belewbekele@yahoo.com) \\ *Corresponding author \\ e-mail:ww@njau.edu.cn \\ (Received 13 ${ }^{\text {th }}$ May 2017; accepted $2^{\text {nd }}$ Aug 2017)
}

\begin{abstract}
The rapid economic development resulting from Chinese economic reform has greatly accelerated urbanization and industrialization, thus leading to alterations in the natural landscape. Understanding the extent of these changes is important for regional sustainable land management. An integrated approach with a geographic information system and remote sensing was used to extract land use/land cover (LULC) change information for the Su-Xi-Chang region over the period of 1980 to 2010. To calculate the dimensions of fragmentation and to observe changes in spatial patterns, FRAGSTATS was used. Major drivers were determined through bivariate statistical analysis of socioeconomic data sources. Three change matrices were constructed for detecting LULC changes from 1980 to 1990, 1990 to 2000 , and 2000 to 2010 . In the study period, farmland, water bodies and wetlands significantly decreased. However, construction land, grassland and woodlands increased considerably. The pattern and composition of the landscape exhibited significant fragmentation for the whole area. Socioeconomic analysis showed that population growth and economic development, urbanization and subsequent construction land expansion, and industrialization were the major socioeconomic drivers of LULC changes. Changes in farmland resulted in decreases in area and production that might impair ecological functions and decrease food production. Therefore, better land use policy would address the consequences of the loss of the natural landscape due to drastic socioeconomic drivers in the region. Further research along these lines should be encouraged, because additional studies will be helpful for the decision makers engaged in planning activities at various levels.
\end{abstract}

Keywords: GIS, temporal changes, landscape ecology, urbanization, landscape pattern

\section{Introduction}

A wide range of drivers associated with social, biophysical, environmental, economic and technological factors lead to land use/land cover (LULC) changes in different parts of the world (Beilin et al., 2014; Tian, 2015). The drivers of these changes may be well known, such as demographic change (Salvati et al., 2017), industrial development (Li et 
al., 2010), agricultural expansion (Kibret et al., 2016), urbanization (Deng et al., 2015; Xian and Crane, 2005), global market forces (Temesgen et al., 2013), and climatological change, such as drought and rainfall variability (Amuti and Luo, 2014; Biazin and Sterk, 2013; Luo and Zhang, 2014; Román-Cuesta et al., 2014), or they may also involve interactions of institutional or cultural impacts (Kindu et al., 2015; Sakayarote and Shrestha, 2017). These drivers have triggered drastic LULC conversions by substituting one type of LULC with another. Through these processes, the pattern, structure and function of the natural landscape are inevitably altered (Lambin et al., 2001), thus consequently influencing the global environment (Amuti and Luo, 2014). Particularly, the socioeconomic drivers are more intense than the physical drivers of these processes (Desalegn et al., 2014). Understanding these factors is vital for forecasting future LULC dynamics by using models (Lambin et al., 2001) or for the design of management strategies and policies for the sustainable management of land resources (Mottet et al., 2006; Turner et al., 1993).

Since the launch of economic reform and the opening-up policy in the late 1970s in China, LULC changes have rapidly taken place, and land use patterns are quite spatially variable throughout the country (Hua et al., 2010; Wei and Ye, 2009). Particularly since the beginning of the $21^{\text {st }}$ century, the rapid socioeconomic development has resulted in remarkable changes in the spatio-temporal distributions of LULC and has adversely affected the natural environment (Deng et al., 2015; Yirsaw et al., 2016). However, because of the diversified and complex driving forces in the country, there are substantial arguments about the extent and magnitude of changes in LULC $(\mathrm{Xu}, 2004)$. Previous studies have revealed different findings on LULC change drivers in different regions of the country. For instance, Wang et al. (2011) have suggested the expansion of residential areas to cause LULC changes at the expense of agricultural land in northeastern China. Long et al. (2009) have proposed that rapid economic developments are major drivers for the process. Li et al. (2010) have claimed that in the eastern fringe of the Tibetan Plateau of China, the changes have occurred because of climate change and human activities. Kuang et al. (2016) have suggested that the expansion of industrialization is an important factor in LULC change in eastern China. Other studies have indicated that land policy is a major influential driver in LULC changes (Liu et al., 2010b).

Though substantial efforts have been made to identify factors driving LULC changes in different parts of the country, those research findings have revealed that the drivers vary from place to place depending on location-specific factors. Moreover, there is significant disagreement regarding the extent of influence by these drivers of changes, thus making generalizations nearly impossible ( $\mathrm{Li}$ and Yeh, 2004; Wu et al., 2013). Therefore, any intervention to address drivers of change for sustainable land management must begin with locally specific understanding of the different drivers affecting the LULC. This requirement is especially true for the Su-Xi-Chang region of eastern coastal China, which has a fragile environment where substantial LULC changes have occurred. In the Su-Xi-Chang region, as stated by Zhou et al. (2014), owing to economic development, different conflicts, such as the conflict between land resources and demand for development versus the vulnerability of the coastal area, have arisen. Moreover, Xie et al. (2007) have suggested that both the existence of rapid economic development and the loose and neglected control of land use have put the LULC management of the region at risk. Thus, it is crucial to determine the dynamics of LULC and the main socioeconomic drivers of the change in this fragile environment. This 
information would facilitate measures to arrest and reverse the situation of LULC changes in the region and would improve understanding of the influence of socioeconomic drivers on LULC changes.

Considering these factors, this paper was designed with the following objectives: (1) to characterize land use dynamics and patterns of LULC change across the study area over the past three decades; (2) to determine the major socioeconomic drivers in periods from 1980 to 2010; and (3) to assess the relationship between LULC changes and the major socioeconomic drivers.

\section{Materials and Methods}

\section{Study area}

Encompassing three municipalities, Suzhou, Wuxi and Changzhou, the Su-Xi-Chang region is located in the Jiangsu Province $\left(36^{0} 46^{\prime}-32^{0} 04^{\prime} \mathrm{N}, 119^{0} 08^{\prime}-121^{0} 15^{\prime} \mathrm{E}\right)$ in the middle of the Yangtze River Delta Economic zone of east China. It covers a total area of $1.7 \times 10^{4} \mathrm{~km}^{2}$, with an average elevation below 50 meters (Fig. 1). The area has a monsoon climate with a mean annual temperature and precipitation of $15.3^{\circ} \mathrm{C}$ and 1,092 mm, respectively (Long et al., 2009).

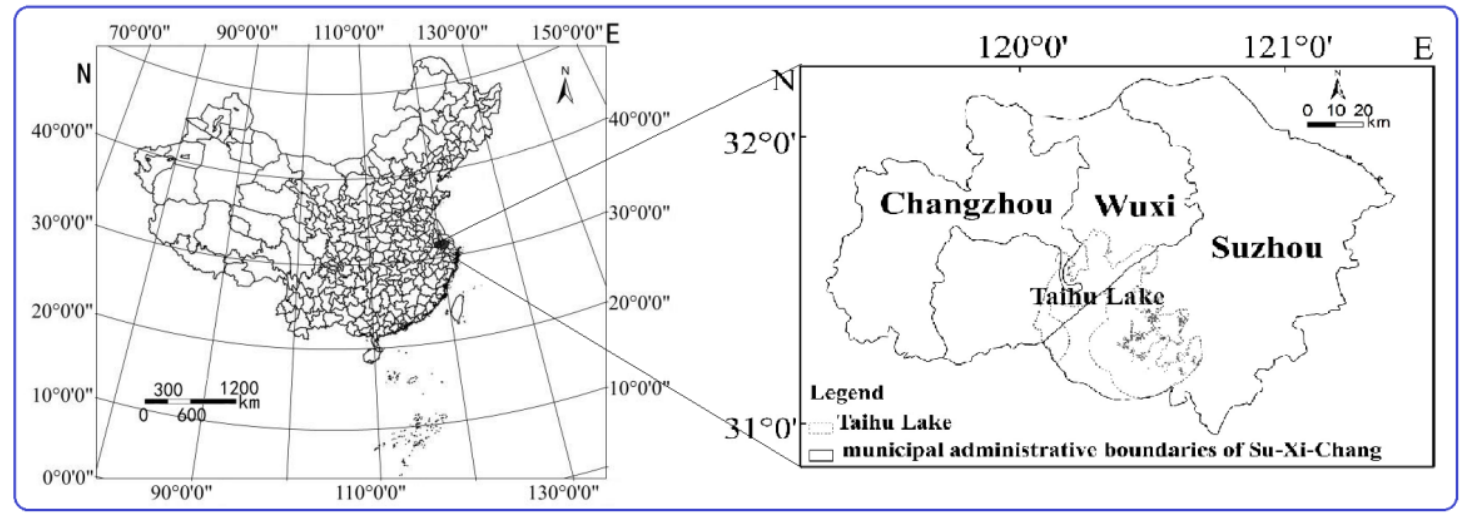

Figure 1. Location of the study area

In 2014 , the region had a total population of 14.55 million $\left(838 / \mathrm{km}^{2}\right)$, which was more than 6 times the total population per $\mathrm{km}^{2}\left(135.5 / \mathrm{km}^{2}\right)$ of the country in the same year. Similarly, the GDP per capita of the Su-Xi-Chang region $(123,325 \mathrm{CNY})$ was three times more than the GDP per capita of the country in the same period (NBSC, 2014). From the early 1980s, the growth of Shanghai has pushed the region toward rapid urbanization and industrialization (Long et al., 2009). Unprecedented changes in the local economy have taken place in recent decades. On the grounds of diversified cooperative enterprises in the mid-1980s, the region has served as a model for the advancement of rural industrialization (Xie et al., 2007; Tan, 1986). With these changes, the $\mathrm{Su}-\mathrm{Xi}$-Chang region has confirmed its position of importance at the national level, and today, it constitutes the Key Economic Zone in Eastern China. However, with the development of economic activities, drastic changes in LULC have been occurring in the region. These changes have prompted concerns and attempts to detect and monitor 
changes in LULC and to assess the main socioeconomic drivers of the changes, in order to attain sustainable land management.

\section{Data source and processing}

For time series LULC changes analysis (1980, 1990, 2000 and 2010), the study used vectored data sets with a $30 \mathrm{~m}$ spatial resolution from Landsat reflectance products and the DEM of the Computer Network Information Center, Chinese Academy of Science. Additionally, administrative boundaries at the county level were used, which were provided by the Data Sharing Infrastructure of Earth System Science, Institute of Geographic Sciences and Natural Resources Research, Chinese Academy of Science. MSS and TM images were geometrically corrected using ground control points, with ETM+ images as the master and reference images. To identify the agreement in classification consistency and accuracy, effective classification was conducted by using standard procedures (Liu et al., 2005). Accordingly, as shown in Table 1, six land use categories were classified for the four study periods: farmland, construction land, grassland, woodland, water body, and wetland. The ESRI ArcGIS spatial analysis model was applied to measure variation within LULC types. A set of pattern metrics was identified to examine cover change spatial patterns, and FRAGSTATS was used to compute the dimension of fragmentation. In addition, a time series of socioeconomic data on population, industrial output value, agricultural production (crop yield), aquatic products, GDP, agricultural land, and construction land (settlement areas) from 1980 to 2010 was collected from local government offices and statistical year books for the region (Appendix A). These data were used to analyze the potential socioeconomic driving forces triggering LULC changes in the Su-Xi-Chang region.

\section{Methods}

Mainly on the basis of classified and gridded land use polygon themes (Fig. 2), internal change variations were computed between each consecutive map (from 1980 to 1990, 1990 to 2000 and 2000 to 2010). For each consecutive pair of gridded time series maps, a transition matrix was assembled (Tables 2, 3 and 4). Then, for each LULC category $m$ in the transition matrix, the conversion between the two periods was computed via the GIS analysis function:

$$
\Delta L_{m}=\left(r_{m}-r_{. m}\right) / r_{. m} \times 100
$$

where $\Delta \mathrm{L}_{m}$ is the change of LULC in row $m$, relative to the previous compared year; $r_{m}$. is the row total of grid cells for category $m$; and $r_{\cdot m}$ is the column total of grid cells for category $m$.

For exploring the internal conversion between different cover types, we treated the change (decrease or increase) for a cover category in a given year relative to a compared year considering various "loss or gain" conversions. Thus, for any type of "conversion loss to" or "conversion gain from", the percentage taken by this type in the total "loss or gain" was calculated as: 


$$
\begin{cases}R_{l o s s(m) n}=\frac{\left(r_{n m}-r_{m n}\right)}{\left(r_{m}-r_{. m}\right)} \times 100 & m \neq n \\ R_{g a i n(m) n}=\frac{\left(r_{m, n}-r_{n, m}\right)}{\left(r_{m}-r_{. m}\right)} \times 100 & m \neq n\end{cases}
$$

where $\mathrm{R}_{\text {loss }(m) n}$ is the percentage taken by type $n$ in the total "conversion loss" of category row $m ; \mathrm{R}_{\operatorname{gain}(m) n}$ is the percentage taken by $n$ in the total "conversion gain" of category row $m$; and $r_{n m}$, and $r_{m n}$ are the individual entries in a change matrix.

Bivariate correlation statistical analysis was performed to assess the relationships between LULC changes and socioeconomic drivers (Table 6). Through examining the spatial change patterns, we identified a set of pattern metrics at both the class and landscape levels that capture different dimensions of land fragmentation. Parker et al. (2001) have observed the absence of a site (region) specific typical set of metrics, as a result of variations in the significance of specific metrics significance based on research objectives and study area characteristics. As indicated by (McGarigal et al., 2002), six major landscape metrics at the class level, including patch density (PD), largest patch index (LPI), number of patches (NP), landscape shape index (LSI), area-weighted mean patch fractal dimension (AWMPFD), and interspersion and juxtaposition (IJI); and six at the landscape level, including Shannon's diversity index (SHDI), number of patches (NP), largest patch index (LPI), area-weighted mean patch fractal dimension (AWMPFD), contagion index (CONTAG) and interspersion and juxtaposition (IJI), were selected for this study on the basis of our research objectives and study area characteristics. These indices were calculated using FRAGSTATS, a spatial pattern analysis program for categorical maps (Table 5, and Fig. 3).

\section{Result and discussion}

\section{Spatial patterns of LULC dynamics}

Figure 2 shows the spatial pattern of LULC changes for the years 1980, 1990, 2000 and 2010 of the study area. In 1980, farmland and water body were the dominant cover types, and the direction of urban development (collectively termed construction land) was confined to the central part of the three municipalities - Su Zhou, $\mathrm{Wu} \mathrm{Xi}$ and Chang Zhou of the Su-Xi-Chang region (Fig. 2).

However, in 1990, construction land started to replace some of the farmland. The construction land development tended to extend further in the north and northeast directions between 1980 and 1990, when the region embarked on economic reform by developing collective enterprises at the start of the age of rapid urban and industrial development. In the 1980s, township enterprises expanded with the formation of various small towns in the region (Long et al., 2009). After 1990, construction land became more prevalent, and the pace of urbanization and industrialization was considerably accelerated. Particularly at the end of 2010, the area of construction land overtook the area of farmland (Fig. 2) and covered more than $29 \%$ of the studied landscape (Table 1). However, farmlands started to vanish at the same time, because the demand for construction land dramatically increased with socioeconomic development. 

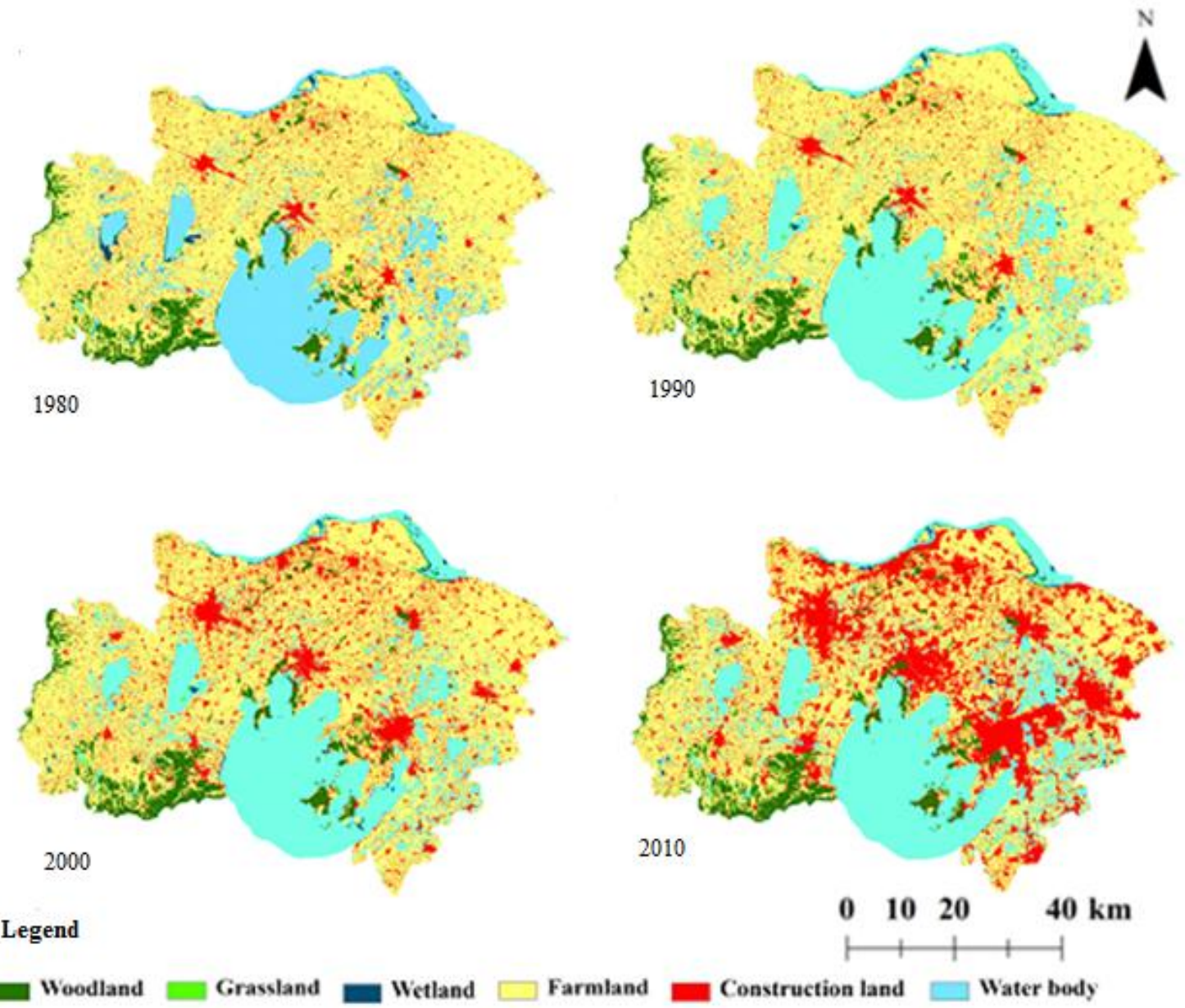

Legend

Woodland Grassland

Wetland $\square$ Farmland

Construction land Water body

Figure 2. LULC maps of the Su-Xi-Chang region for the years 1980, 1990, 2000 and 2010

Table 1. Temporal patterns of LULC changes of the Su-Xi-Chang region

\begin{tabular}{|c|c|c|c|c|c|c|c|c|c|c|}
\hline \multirow{2}{*}{ LULC type } & \multicolumn{2}{|l|}{1980} & \multicolumn{2}{|l|}{1990} & \multicolumn{2}{|l|}{2000} & \multicolumn{2}{|l|}{2010} & \multicolumn{2}{|c|}{ Change $(1980-2010)$} \\
\hline & Area (ha) & $\%$ & Area (ha) & $\%$ & Area (ha) & $\%$ & Area (ha) & $\%$ & Total & $\%$ \\
\hline Farmland & 977,687 & 56.04 & 922,383 & 52.87 & 864,338 & 49.54 & 647,986 & 37.14 & $-329,701$ & -33.71 \\
\hline Woodland & 114,796 & 6.58 & 116,890 & 6.78 & 117,154 & 6.72 & 119,831 & 6.87 & 5,035 & 4.37 \\
\hline Grassland & 1919 & 0.11 & 1745 & 0.11 & 1592 & 0.09 & 2203 & 0.13 & 284 & 14.81 \\
\hline Water body & 514,839 & 29.51 & 516,757 & 29.61 & 499,309 & 28.62 & 485,055 & 27.8 & $-29,784$ & -5.79 \\
\hline Wetland & 7153 & 0.41 & 5059 & 0.31 & 3672 & 0.21 & 3454 & 0.20 & $-3,699$ & -51.71 \\
\hline $\begin{array}{l}\text { Construction } \\
\text { land }\end{array}$ & 126659 & 7.26 & 181,790 & 10.32 & 258,559 & 14.82 & 486,095 & 27.86 & 359,436 & 284.81 \\
\hline Total & $1,744,624$ & 100 & $1,744,624$ & 100 & $1,744,624$ & 100 & $1,744,624$ & 100 & - & - \\
\hline
\end{tabular}

\section{Analysis of temporal LULC changes}

The general tendency of change in LULC during the thirty-year period is indicated in Table 1. On the basis of the land use transition matrix, the comprehensive dynamics among different LULC types is shown in Tables 2, 3 and 4 . With 56\% coverage of the study area, farmland was the dominant cover type in 1980, followed by water body 
(30\%). In the same period, construction land covered only $7 \%$ of the studied landscape (Table 1). In 1990, farmland decreased to 53\% and water body was slightly balanced $(30 \%)$, and both are the dominant LULC types. However, construction land increased by $3.2 \%$ of the preceding period, covering more than $10 \%$ of the total study area during this period (Table 1).

From 1980 to 1990, construction land, woodland, and water body enlarged by $3.4 \%$, $0.2 \%$, and $4 \%$, respectively. In contrast, farmland, grassland, and wetland decreased by $1.3 \%, 9.6 \%$, and $39 \%$, respectively (Table 2). In this period, farmland was the main contributor to an increase in the areas of woodland, water body, and construction land by allowing for $27 \%, 48 \%$, and $79 \%$ of the increase in their total area, respectively (Table 2). In this period, the grain for green development policy, expansion of artificial ponds for fish production, and urban expansion were the main reasons for the large amount of farmland conversion.

Table 2. LULC conversion matrix from 1980 to 1990 (ha)

\begin{tabular}{llllllllcc}
\hline & & & & & & & & \multicolumn{2}{c}{ Change 1990 } \\
\cline { 5 - 8 } Land use type & FL & WOL & GL & WB & WL & CL & Sum & Total & \% \\
\hline Farmland (FL) & 922,011 & 106 & 10 & 110 & 94 & 263 & 922,383 & $-55,304$ & -5.71 \\
Woodland (WOL) & 591 & 114,656 & 204 & 2 & 6 & 2 & 116,890 & 2,094 & 1.79 \\
Grassland (GL) & 396 & 13 & 1648 & 9 & 12 & 1 & 1745 & -174 & -9.01 \\
Water body (WB) & 9386 & 10 & 52 & 514,449 & 2830 & 3 & 516,757 & 1918 & 0.39 \\
Wetland (WL) & 1098 & 0 & 4 & 154 & 4181 & 13 & 5059 & $-2,094$ & -29.31 \\
$\begin{array}{l}\text { Construction land } \\
\text { (CL) }\end{array}$ & 44205 & 11 & 1 & 15 & 30 & 126477 & 181,790 & 5,513 & 4.35 \\
Sum 1980 & 977,687 & 114,796 & 1919 & 514,839 & 7153 & 126659 & $1,744,624$ & - \\
\hline
\end{tabular}

From 1990 to 2000 farmland, grassland, and wetland continued decreasing by more than $6 \%, 8 \%$, and $27 \%$ respectively. In addition to these three LULC categories water bodies started to decrease with more than $3 \%$ of its total area of the base year in the same period; however, woodland, and construction land expanded by $0.3 \%$, and $42 \%$, respectively (Table 3). In this period, the diminishing of farmland contributed $100 \%$, and $5 \%$ to the expansion of construction land, and woodland, respectively (Table 3). In the period between 2000 and 2010, a comparable LULC change pattern was found, in which construction land continued to increase at an alarming rate, and was followed by grassland and woodland. The decreasing farmland area caused an increase in the areas of construction land, woodland, and grassland by $76 \%, 93 \%$, and $100 \%$, respectively (Table 4). In addition, a reduction in wetland area contributed $4 \%$ toward the expansion of construction land in the same period (Table 4). Thus, as lands supporting construction land expansion became scarce, wetlands the target for construction development. Our result supports the findings of Wang et al. (2011), who have found that the expansion of construction land in the West Songneu Plain of China led to the shrinking and fragmentation of swamplands. Similarly, Yuan Zhang (2010) has described the same phenomenon in the Yinchuan Plain of China.

Considering the LULC conversion matrix from 1980 to 2010, there was considerable growth in construction land over the other LULC types; remarkably, this growth far exceeded the amount of land converted from construction land to other LULC types. 
The results (Tables 2, 3 and 4) showed that over the study period, the loss of farmland strongly contributed to the newly emerging construction land, and was followed by wetland and water bodies, respectively. Thus, driven by robust socioeconomic factors, the ongoing growth in construction land was responsible for a large decline in the farmlands, wetlands and water bodies in the region.

Table 3. LULC conversion matrix from 1990 to 2000 (ha)

\begin{tabular}{llllllllll}
\hline Land use type & FL & WOL & GL & WB & WL & CL & Sum 2000 & $\begin{array}{l}\text { Total } \\
\text { (ha) }\end{array}$ \\
\hline Farmland (FL) & 828,938 & 198 & 0 & 2 & 1 & 1331 & 864,338 & $-58,045$ & -6.29 \\
Woodland (WOL) & 185 & 113,840 & 0 & 0 & 0 & 1 & 117,154 & 264 & 0.23 \\
Grassland (GL) & 6 & 58 & 1695 & 155 & 0 & 1 & 1592 & -153 & -8.77 \\
Water body (WB) & 8763 & 34 & 6 & 516,032 & 185 & 221 & 499,309 & -17448 & -3.38 \\
Wetland (WL) & 1 & 0 & 3 & 0 & 4856 & 110 & 3672 & -1387 & -27.42 \\
Construction land & 84,490 & 2760 & 41 & 620 & 17 & 180,126 & 258,559 & 76769 & 42.23 \\
(CL) & & & & & & & & & \\
Sum 1990 & 922,383 & 116,890 & 1745 & 516,757 & 5059 & 181,790 & $1,744,624$ & - & - \\
\hline
\end{tabular}

Table 4. LULC conversion matrix from 2000 to 2010 (ha)

\begin{tabular}{llllllllll}
\hline Land use type & FL & WOL & GL & WB & WL & CL & $\begin{array}{l}\text { Sum } \\
2010\end{array}$ & $\begin{array}{l}\text { Total } \\
\text { (ha) }\end{array}$ \\
\hline Farmland (FL) & 646,970 & 703 & 23 & 96 & 18 & 6205 & 647,986 & $-216,352$ & -25.02 \\
Woodland (WOL) & 2593 & 111,390 & 16 & 50 & 0 & 109 & 119,831 & 2,677 & 2.27 \\
Grassland (GL) & 1124 & 2226 & 1274 & 58 & 1 & 155 & 2203 & 611 & 38.38 \\
Water body (WB) & 33,412 & 457 & 185 & 487,479 & 67 & 2456 & 485,055 & $-14,254$ & -2.85 \\
Wetland (WL) & 186 & 35 & 0 & 1498 & 3492 & 554 & 3454 & -218 & -5.93 \\
Construction land & 179,952 & 2343 & 94 & 10,128 & 94 & 249,044 & 486,095 & 227,536 & 88.01 \\
(CL) & 864,338 & 117,154 & 1592 & 499,309 & 3672 & 258,559 & $1,744,624$ & - & - \\
\hline Sum 2000 & & & & & & & & &
\end{tabular}

\section{Analysis of landscape metrics}

The overall trends of LULC fragmentation at both class (Table 5) and landscape (Fig. 3) levels were considered. The detailed descriptions of landscape metrics used in this study are given in Appendix B. As shown in Table 5, the landscape change for farmland and wetland at the class level indicated a consistent increase in the number of patches (NP) that enhanced the corresponding patch density during the study period. For farmland, NP increased from 357 in 1980 to 383 in 1990 and to 539 and 812 in 2000 and 2010, respectively, thus indicating that the spatial heterogeneity of this class increased with increasing disturbance over time. A similar pattern was found in the wetland category, as evidenced by increased patch density (PD) (Table 5). This result suggested that in recent decades, increasing human pressure has led to the fragmentation of both farmland and wetland LULC categories. The largest patch index (LPI) for both farmland and wetland showed a declining trend throughout the study period, owing to the intensification of construction land. For instance, the LPI for the wetland category 
decreased from $10.12 \%$ in 1980 to $2.04 \%$ in 2010 . Likewise, the LPI for farmland decreased from $38.7 \%$ in 1980 to $27.5 \%$ in 2010 (Table 5). Furthermore, interspersion and juxtaposition (IJI) indicated identical configurations for both LULC types, thus indicating that the patch types of these LULC categories were more scattered.

Apart from farmland and wetland, and except for construction land, the rest of the LULC types showed irregular stability with variable values. However, as observed in the LULC change analysis (Tables 2, 3, 4; and Fig. 2), construction land has rapidly replaced farmland in the Su-Xi-Chang region. The NP for construction land was 10,510 in 1980, decreased to 10,252 in 1990 and increased to 10,835 in 2000, but in 2010, markedly decreased to 7641. The rapid urban development between 1990 and 2000 might have resulted in the large NP in 2000. The PD values also showed that the construction land became denser over time, a result also confirmed by its IJI values, which kept increasing, thus indicating that the construction land category has a continuous and clumped pattern.

Table 5. Landscape metrics changes according to patch class level in the Su-Xi-Chang region

\begin{tabular}{|c|c|c|c|c|c|c|c|}
\hline Class & Year & NP & PD & LSI & LPI & AWMPFD & IJI \\
\hline \multirow[t]{4}{*}{ Farmland } & 1980 & 357 & 0.0205 & 69.0205 & 38.7074 & 1.1 & 62.2521 \\
\hline & 1990 & 383 & 0.022 & 75.9841 & 34.2572 & 1.02 & 61.1539 \\
\hline & 2000 & 539 & 0.031 & 93.1932 & 30.2799 & 1.21 & 56.0708 \\
\hline & 2010 & 812 & 0.0467 & 103.8536 & 27.4821 & 1.26 & 56.7936 \\
\hline \multirow[t]{4}{*}{ Woodland } & 1980 & 609 & 0.0363 & 38.8551 & 1.4845 & 1.26 & 41.071 \\
\hline & 1990 & 641 & 0.035 & 38.5286 & 1.4822 & 1.23 & 41.2144 \\
\hline & 2000 & 631 & 0.0369 & 39.9257 & 1.4601 & 1.06 & 50.6993 \\
\hline & 2010 & 640 & 0.0368 & 40.9147 & 11.4319 & 1.02 & 60.4878 \\
\hline \multirow[t]{4}{*}{ Grassland } & 1980 & 141 & 0.009 & 19.184 & 0.0385 & 1.23 & 88.902 \\
\hline & 1990 & 156 & 0.0081 & 18.8301 & 0.0215 & 1.03 & 89.8603 \\
\hline & 2000 & 152 & 0.009 & 19.5546 & 0.0214 & 1.01 & 93.1942 \\
\hline & 2010 & 157 & 0.0145 & 24.5787 & 10.0182 & 1.02 & 92.6445 \\
\hline \multirow[t]{4}{*}{ Water body } & 1980 & 2447 & 0.1407 & 40.8143 & 17.835 & 1.25 & 41.1412 \\
\hline & 1990 & 2201 & 0.1265 & 39.4735 & 16.1191 & 1.2 & 39.6078 \\
\hline & 2000 & 2548 & 0.1465 & 42.6489 & 15.187 & 1.26 & 43.7562 \\
\hline & 2010 & 2534 & 0.1457 & 47.0361 & 14.477 & 1.16 & 47.2235 \\
\hline \multirow[t]{4}{*}{ Wetland } & 1980 & 219 & 0.0126 & 42.3869 & 10.1173 & 1.08 & 61.3066 \\
\hline & 1990 & 225 & 0.0143 & 52.7915 & 8.054 & 1.05 & 61.0185 \\
\hline & 2000 & 238 & 0.0145 & 68.0608 & 5.0451 & 1.14 & 62.1501 \\
\hline & 2010 & 287 & 0.0152 & 75.2681 & 2.0428 & 1.23 & 70.0982 \\
\hline \multirow{4}{*}{$\begin{array}{l}\text { Construction } \\
\text { land }\end{array}$} & 1980 & 10510 & 0.6043 & 138.6259 & 10.3137 & 1.2 & 14.5744 \\
\hline & 1990 & 10252 & 0.5895 & 135.9465 & 20.3498 & 1.26 & 14.7907 \\
\hline & 2000 & 10835 & 0.623 & 132.7572 & 26.7967 & 1.06 & 20.3902 \\
\hline & 2010 & 7641 & 0.4393 & 97.3106 & 33.3579 & 1.05 & 29.8143 \\
\hline
\end{tabular}

$\mathrm{NP}=$ number of patches; $\mathrm{PD}=$ patch density; LSI = landscape shape index; LPI = largest patch index; AWMPFD = area-weighted mean patch fractal dimension; and IJI = interspersion and juxtaposition. 
To designate the characteristic features of the fragmentation of LULC at the landscape level and to evaluate the extent of human pressure causing changes on landscape structure, the NP, LPI, AWMPFD, IJI, Shannon's diversity index (SHDI), and contagion index (CONTAG) were computed by using FRAGSTATS, and the results are presented in Fig. 3. The opposite magnitudes between LPI and NP at the landscape level (Fig. 3a, and $b$ ) indicated high landscape fragmentation. Thus increasing human activities in the region have caused a dispersed landscape structure. In addition, the continuously increasing value of AWMPFD indicated clear fragmentation of LULC at the landscape level (Fig. 3c). A continuous decline in values of SHDI indicated that the landscape was unevenly distributed and subjected to less patch types. The SHDI decreased from 1.2608 in 1980 to 1.1382 in 1990, and from 1.0377 in 2000 to 1.0352 in 2010 (Fig. 3d), possibly as a result of urban landscape dominance. The CONTAG value was lower in 1990 than in 1980. However, the values again became higher after 2000, thus suggesting a more contiguous and homogenous pattern. The analysis showed that the intensification of human activities in the study area has caused landscape fragmentation, thereby leading to the loss of the function of a natural landscape.
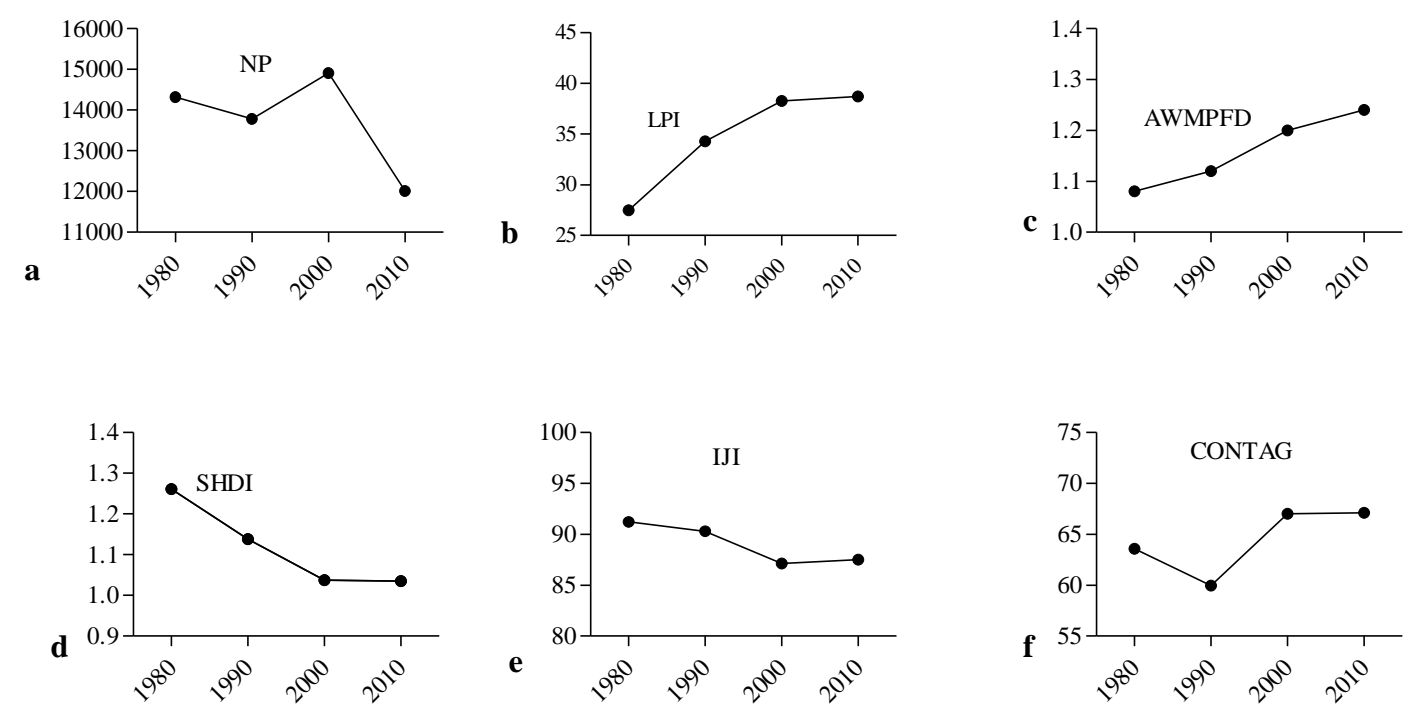

Figure 3. Changes in number of patches (NP), largest patch index (LPI), area-weighted mean patch fractal dimension (AWMPFD), Shannon's (SHDI), interspersion and juxtaposition (IJI) and contagion index (CONTAG) at the landscape level

\section{Analysis of major socioeconomic drivers}

Combinations of various socioeconomic factors have induced LULC changes in the $\mathrm{Su}-\mathrm{Xi}$-Chang region. Table 6 depicts the relationships among these different socioeconomic variables and LULC changes. In addition, Appendix A shows the various socioeconomic variables considered in this study along with their detailed values over the past thirty-years. The overall results of our statistical analysis showed that over the past three decades, population growth and economic development, urbanization and subsequent construction land expansion, and rapid industrialization were the major drivers of LULC changes in the Su-Xi-Chang region. 


\section{Population growth and economic development}

The total population of the Su-Xi-Chang region was approximately 11 million in 1980, and suddenly increased to 13 million within a decade in 1990, with an annual growth rate of $8.6 \%$. In 2000 , the population rose to 13.5 million, and in 2010 , it reached 14.5 million. In 2014, the population reached more than 15.2 million (NBSC, 2015). After population growth, LULC changes in the region became aggravated over time (Table 1). Different authors, particularly those in developing countries, have suggested that increased population growth causes LULC changes (Garedew et al., 2009; Kamusoko and Aniya, 2007).

Our results showed that the relationship between the growth in population and construction land was positively correlated $(r=0.631)$, and the values were significantly different $(\mathrm{P}<0.05)$. This result suggested that the increase in population also caused the increase in construction land expansion (Table 6), possibly because of an increase in settlement demand, for which large parts of agricultural lands were changed to residential areas, both in rural and urban zones. This possibility was confirmed by the inverse relationship between population growth and agricultural land (Table 6). Furthermore, the negative correlation between these two factors may suggest the importance of population growth in the LULC changes occurring in the region. This result is consistent with findings from Priess et al. (2007) in Indonesia and Kidane et al. (2012) in Ethiopia, which have shown that increases in population growth lead to agricultural land loss. Because Su-Xi-Chang is a potential region for agricultural production, a large part of this region is still in the agricultural sector. To meet the demands of the growing population by producing high production from limited land resources, large areas of agricultural land were converted into alternative productive land use practices, such as fishponds for fish farming, as evidenced by the strong positive relationship between the growth of population and increase in aquatic products (Table 6; Fig. 4).

Table 6. Correlation coefficients between different socioeconomic variables

\begin{tabular}{|c|c|c|c|c|c|c|c|}
\hline & Population & $\begin{array}{l}\text { Industrial } \\
\text { output }\end{array}$ & $\begin{array}{l}\text { Agricultural } \\
\text { production }\end{array}$ & $\begin{array}{l}\text { Aquatic } \\
\text { products }\end{array}$ & GDP & $\begin{array}{l}\text { Agricultural } \\
\text { land }\end{array}$ & $\begin{array}{l}\text { Construc- } \\
\text { tion land }\end{array}$ \\
\hline Population & 1 & $.407^{*}$ & -.307 & $.479^{* *}$ & $.405^{*}$ & $-.447^{*}$ & $.631^{*}$ \\
\hline Industrial output & & 1 & $-.882^{* *}$ & $.715^{* *}$ & $.999^{* *}$ & $-.979^{* *}$ & $.976^{* *}$ \\
\hline Agricultural production & & & 1 & $-.704^{* *}$ & $-.867^{* *}$ & $.880^{* *}$ & $-.905^{* *}$ \\
\hline Aquatic products & & & & 1 & $.706^{* *}$ & $-.826^{* *}$ & $.815^{* *}$ \\
\hline GDP & & & & & 1 & $-.973^{* *}$ & $.971^{* *}$ \\
\hline Agricultural land & & & & & & 1 & $-.982^{* *}$ \\
\hline Construction land & & & & & & & 1 \\
\hline
\end{tabular}

* Correlation is significant at the 0.05 level (2-tailed).

** Correlation is significant at the 0.01 level (2-tailed).

In addition to population growth, economic development showed a positive correlation ( $\mathrm{r}=0.971)$ with construction land, and the relationship was highly significant $(\mathrm{P}<0.01)$ (Table 6). Thus, an increase in economic development also caused an increase in 
construction land expansion. This result is in line with findings from Tang et al. (2014) in Harbin, Northeast China, which have indicated that economic development can cause LULC changes that significantly affect the functions of a natural landscape. Given the advantage of its location, being in a coastal area of the country, the economy of the Su-XiChang region showed an upward trajectory (Fig. 4a), and currently, the region plays a vital role in the Chinese economy. This observation also accounted for the rapid expansion of urban and industrial lands that led to LULC change. Hence, our results showed that in general, the growth of the population and economic developments were the principal causal factors of changes in the LULC of the study area.

\section{Industrialization}

In the study period, industrialization in the Su-Xi-Chang region explosively increased after the rapid rise in the total industrial output value (Fig. 4a), which also caused major LULC changes. An all-around rapid industrialization and urbanization occurred in the region since 2000, owing to a higher consumption of land for industrialization than for urbanization. During this period, to support the manufacturing expansion, less attention was given to agricultural land. As a result, urban associated industrialization became an essential driving force of LULC changes, thereby decreasing the arable land category. Rural industrialization has been reported to contribute to construction land expansions in China (Lin and Ho, 2003). This phenomenon also occurred in the Su-Xi-Chang region, as evidenced by the strong positive correlation between construction land and the industrial output value $(r=$ 0.976) with a significant difference of $\mathrm{P}<0.01$.
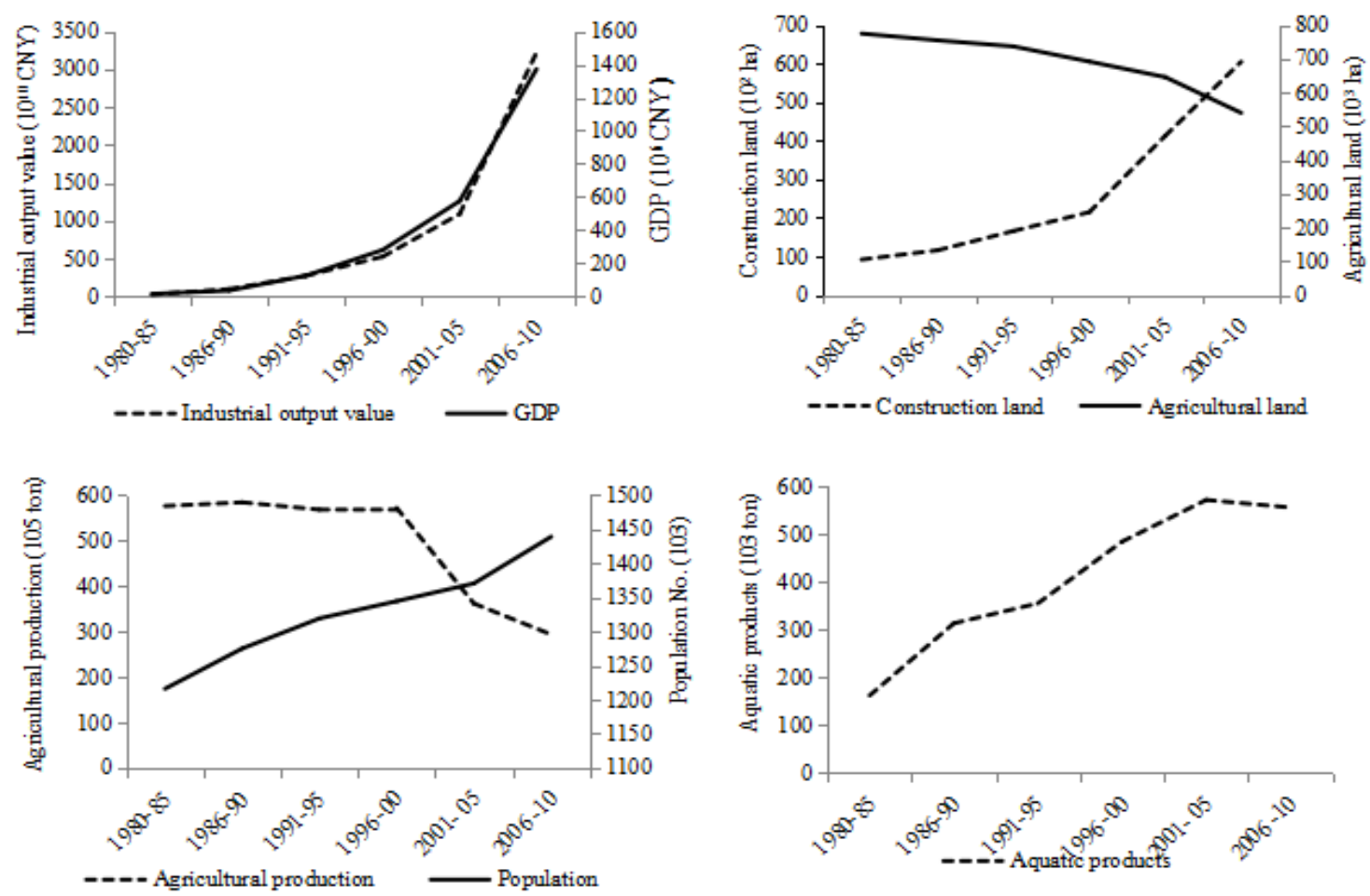

Figure 4. Trends in different socioeconomic variables from 1980 to 2010 in the Su-Xi-Chang region 
As indicated in Table 6, there was a strong positive correlation between aquatic products and the industrial output value $(\mathrm{r}=0.715)$ and between GDP and the industrial output value $(r=0.999)$, both of which exhibited significant differences $(P<0.01)$. These findings suggested that increases in both aquatic products and GDP contributed to the increase in industrial output. This finding may have been due to an increase in the row material supply from increased aquatic products, as well as to an increase in GDP, which enhanced the output values of industries. However, the industrial output value was negatively correlated with agricultural production $(\mathrm{r}=-0.882)$ and agricultural land $(\mathrm{r}=-0.979)$, and the relationships were highly significant $(\mathrm{P}<0.01)$, thus indicating the effect of industrialization from the massive conversion of agricultural land into market oriented land use. Put another way, the results indicated that industrialization has cursorily caused substantial loss of agricultural land, to the benefit of market oriented farming and non-agricultural development.

In addition, owing to economic prosperity, particularly by the middle of the 1980s, the region provided a model for the development of rural industries. This model also describes when the Township and Village Enterprises (TVEs) thrived after rapid growth of the rural economy in southern Jiangsu (Long et al., 2009). Since then, the growth of TVEs and the development of an export-oriented economy have fundamentally transformed the industrial pattern of the region. As a result, the total industrial output value markedly increased (Fig. 4a). These manifestations played roles in LULC changes, as evidenced by the strong inverse relationship between industrial output values and the loss in agricultural land (Table 6).

\section{Urbanization and subsequent construction land expansion}

Rapid urbanization was stimulated after the Chinese economic reform of the 1970s, particularly around the beginning of the 1990s, and urbanization was accelerated to a great extent as the centrally planned economy shifted to a socialist market. This shift led to construction land expansion (Xu, 2004; Liu et al., 2005) and subsequently to the loss of agricultural land in China (Kuang et al., 2016). In the Su-Xi-Chang region, the area of construction land, mainly owing to urbanization, increased from 126,659 ha in 1980 to 181,790 ha in 1990 , with an annual growth rate of $4.35 \%$ (Table 1). In 2000, it attained a total area of 258,559 ha, and in 2010, it increased by 227,536 ha more than that in the former period, in which farmland contributed $76 \%$ of the amplification (Table 4). These changes were evidenced by the strong inverse relationship between construction land and agricultural land (Table 6; Fig. 4b). In the past three decades, notably, construction land increased by 359,436 ha, amounting to $284.81 \%$ of the area in 1980, during which it covered merely $7 \%$ of the total landscape, which rose to $27.86 \%$ in 2010 (Table 1).

The results showed that areas of $79 \%, 100 \%$, and $76 \%$ enlargement in construction land from 1980 to1990, 1990 to 2000, and 2000 to 2010, respectively, were contributed by farmland (Tables 2, 3, and 4). As (Liu et al., 2008) have described, this type of occupation mostly occurred in the developed areas, especially in the main grain production zone of the coastal regions, thus leading to simultaneous decreases in both the area and production of agricultural land (Fig. $4 b$ and c). Particularly, the decrease in production occurred because the productive lands occupied by construction land and crop cultivation were forced to be located in less productive areas. This scenario can be seen in Table 6, which shows the negative relationship between agricultural production 
and construction land $(\mathrm{r}=-0.905)$ as well as agricultural land and construction land $(\mathrm{r}=$ -0.982), with a highly significant correlation $(\mathrm{P}<0.01)$.

The occurrence of various development activities in the region also played vital roles in the construction land expansion, which was followed by a decrease in agricultural land (Fig. 4b). For instance, the construction of a special development zone, the ETDZ, in Kunshan City of the Su-Xi-Chang region originated in 1985 (Long et al., 2007). It was approximately 375 ha before it was chosen as one of the state development zones. After a decade, its planning area increased by more than $500 \%$, and it attained a total area of 2000 ha. Correspondingly, the advent of TVEs to increase farmers' nonagricultural income by promoting the structural adjustment and institutional innovation made a vital contribution to the process of expanding construction land, thus resulting in conversion of large areas of agricultural land for rural village construction. Thus, urbanization and the subsequent expansion of construction land was generally one of the most important factors in LULC change in the studied landscape.

\section{Conclusion}

We examined the spatio-temporal dynamics of LULC changes, major socioeconomic drivers, and the relationship between changes in LULC and their drivers in the Su-XiChang region over the course of 1980 to 2010. Significant changes in LULC were found in the region, whereby construction land dramatically increased largely at the expense of farmland. From 1980 to 1990, diminishing farmland was more important for the newly emerged construction land, as well as for the enlargement of water bodies and woodland, than the other cover types. In the same period, dwindling wetland contributed to construction land and water body increases next to farmland. Similar trends of conversion occurred in the periods from 1990 to 2000 and 2000 to 2010, except for variations in the spatial extent of changes among the different categories. In addition, changes in landscape patterns and composition exhibited increased the fragmentation of farmland and wetlands. However, the construction land category became aggregated and complex, thereby resulting in the high fragmentation of other LULC categories.

Population growth and economic development, urbanization and subsequent construction land expansion, and industrialization were found to be the major change drivers. The growth of population over time increased the demand for residential areas, and hence, large areas of farmland were converted for settlement construction. Furthermore, to achieve more economic benefits from their farmland, farmers practiced profit oriented farming systems, particularly by converting their farmland into artificial ponds for fish production. Similarly, the rapid industrialization consumed large areas of farmland. In general, the marked expansion of construction land is mainly accountable for the $33 \%$ decrease in farmland in the past three decades.

Given the current trends of socioeconomic drivers in the $\mathrm{Su}-\mathrm{Xi}$-Chang region, increasing pressure on LULC is causing an alarming change in farmland, water bodies, and wetland. The change in farmland involves decreases in both area and production and may impair the ecological functions that support the human dominated environment and result in a decline in food production. Therefore, policies to achieve long term sustainable development must address the effects of these drivers on LULC changes. Moreover, further research along these lines should be encouraged because additional studies will be helpful for the decision makers engaged in planning activities at various levels in the region. 
Acknowledgments. The authors are thankful to the National Natural Science Foundation of China (Fund No. 41571176) for financial support and encouragement in conducting this study.

\section{REFERENCES}

[1] Amuti, T., Luo, G. (2014): Analysis of land cover change and its driving forces in a desert oasis landscape of Xinjiang, northwest China. - Solid Earth 5: 1071.

[2] Beilin, R., Lindborg, R., Stenseke, M., Pereira, H.M., Llausàs, A., Slätmo, E., Cerqueira, Y., Navarro, L., Rodrigues, P., Reichelt, N. (2014): Analysing how drivers of agricultural land abandonment affect biodiversity and cultural landscapes using case studies from Scandinavia, Iberia and Oceania. - Land Use Policy 36: 60-72.

[3] Biazin, B., Sterk, G. (2013): Drought vulnerability drives land-use and land cover changes in the Rift Valley dry lands of Ethiopia. - Agriculture, ecosystems \& environment 164: 100-113.

[4] Deng, X., Huang, J., Rozelle, S., Zhang, J., Li, Z. (2015): Impact of urbanization on cultivated land changes in China. - Land Use Policy 45: 1-7.

[5] Desalegn, T., Cruz, F., Kindu, M., Turrión, M., Gonzalo, J. (2014): Land-use/land-cover (LULC) change and socioeconomic conditions of local community in the central highlands of Ethiopia. - International Journal of Sustainable Development \& World Ecology 21: 406-413.

[6] Garedew, E., Sandewall, M., Söderberg, U., Campbell, B.M. (2009): Land-use and landcover dynamics in the central rift valley of Ethiopia. - Environmental management 44: 683-694.

[7] Hua, L., Li, X., Tang, L., Yin, K., Zhao, Y. (2010): Spatio-temporal dynamic analysis of an island city landscape: a case study of Xiamen Island, China. - International Journal of Sustainable Development \& World Ecology 17: 273-278.

[8] Kamusoko, C., Aniya, M. (2007): Land use/cover change and landscape fragmentation analysis in the Bindura District, Zimbabwe. - Land degradation \& development 18: 221233.

[9] Kibret, K.S., Marohn, C., Cadisch, G. (2016): Assessment of land use and land cover change in South Central Ethiopia during four decades based on integrated analysis of multi-temporal images and geospatial vector data. - Remote Sensing Applications: Society and Environment 3: 1-19.

[10] Kidane, Y., Stahlmann, R., Beierkuhnlein, C. (2012): Vegetation dynamics, and land use and land cover change in the Bale Mountains, Ethiopia. - Environmental Monitoring and Assessment 184: 7473-7489.

[11] Kindu, M., Schneider, T., Teketay, D., Knoke, T. (2015): Drivers of land use/land cover changes in Munessa-Shashemene landscape of the south-central highlands of Ethiopia. Environmental Monitoring and Assessment 187: 452.

[12] Kuang, W., Liu, J., Dong, J., Chi, W., Zhang, C. (2016): The rapid and massive urban and industrial land expansions in China between 1990 and 2010: A CLUD-based analysis of their trajectories, patterns, and drivers. - Landscape and Urban Planning 145: 21-33.

[13] Lambin, E.F., Turner, B.L., Geist, H.J., Agbola, S.B., Angelsen, A., Bruce, J.W., Coomes, O.T., Dirzo, R., Fischer, G., Folke, C. (2001): The causes of land-use and landcover change: moving beyond the myths. - Global environmental change 11: 261-269.

[14] Li, X., Yeh, A.G.-O. (2004): Analyzing spatial restructuring of land use patterns in a fast growing region using remote sensing and GIS. - Landscape and Urban Planning 69: 335354.

[15] Li, Y., Long, H., Liu, Y. (2010): Industrial development and land use/cover change and their effects on local environment: a case study of Changshu in eastern coastal China. Frontiers of Environmental Science \& Engineering in China 4: 438-448. 
[16] Lin, G.C., Ho, S.P. (2003): China's land resources and land-use change: insights from the 1996 land survey. - Land Use Policy 20: 87-107.

[17] Liu, J., Liu, M., Tian, H., Zhuang, D., Zhang, Z., Zhang, W., Tang, X., Deng, X. (2005): Spatial and temporal patterns of China's cropland during 1990-2000: an analysis based on Landsat TM data. - Remote sensing of Environment 98: 442-456.

[18] Liu, Y., Wang, L., Long, H. (2008): Spatio-temporal analysis of land-use conversion in the eastern coastal China during 1996-2005. - Journal of Geographical Sciences 18: 274282.

[19] Liu, Y.S., Wang, J.Y., Long, H.L. (2010b): Analysis of arable land loss and its impact on rural sustainability in Southern Jiangsu Province of China. - J Environ Manage 91: 646653.

[20] Long, H., Heilig, G.K., Li, X., Zhang, M. (2007): Socio-economic development and landuse change: Analysis of rural housing land transition in the Transect of the Yangtse River, China. - Land Use Policy 24: 141-153.

[21] Long, H., Liu, Y., Wu, X., Dong, G. (2009): Spatio-temporal dynamic patterns of farmland and rural settlements in $\mathrm{Su}-\mathrm{Xi}-\mathrm{Chang}$ region: Implications for building a new countryside in coastal China. - Land Use Policy 26: 322-333.

[22] McGarigal, K., Cushman, S.A., Neel, M.C., Ene, E. (2002): FRAGSTATS: spatial pattern analysis program for categorical maps. -

[23] Mottet, A., Ladet, S., Coqué, N., Gibon, A. (2006): Agricultural land-use change and its drivers in mountain landscapes: A case study in the Pyrenees. - Agriculture, ecosystems \& environment 114: 296-310.

[24] NBSC, National Bureau of Statistics of China (2014): China statistical yearbook. Beijing, China Statistics Press.

[25] NBSC, National Bureau of Statistics of China (2015): China statistical yearbook. Beijing, China Statistics Press; 2015.

[26] Parker, D.C., Evans, T., Meretsky, V. (2001): Measuring emergent properties of agentbased land cover/land use models using spatial metrics -

[27] Priess, J., Mimler, M., Weber, R., Faust, H. (2007): Socio-environmental impacts of land use and land cover change at a tropical forest frontier. - MODSIM 2007 International Congress on Modelling and Simulation Modelling and Simulation Society of Australia and New Zealand 349-357.

[28] Román-Cuesta, R., Carmona-Moreno, C., Lizcano, G., New, M., Silman, M., Knoke, T., Malhi, Y., Oliveras, I., Asbjornsen, H., Vuille, M. (2014): Synchronous fire activity in the tropical high Andes: an indication of regional climate forcing. - Global change biology 20: 1929-1942.

[29] Sakayarote, K., Shrestha, R.P. (2017): Policy-driven rubber plantation and its driving factors: a case of smallholders in northeast Thailand. - International Journal of Sustainable Development \& World Ecology 24: 15-26.

[30] Salvati, L., De Zuliani, E., Sabbi, A., Cancellieri, L., Tufano, M., Caneva, G., Savo, V. (2017): Land-cover changes and sustainable development in a rural cultural landscape of central Italy: classical trends and counter-intuitive results. - International Journal of Sustainable Development \& World Ecology 24: 27-36.

[31] Tan, K.C. (1986): Revitalized small towns in China. - Geographical Review 138-148.

[32] Tang, Z., Shi, C., Bi, K. (2014): Impacts of land cover change and socioeconomic development on ecosystem service values. - Environmental Engineering and Management Journal 13: 2697-2705.

[33] Temesgen, H., Nyssen, J., Zenebe, A., Haregeweyn, N., Kindu, M., Lemenih, M., Haile, M. (2013): Ecological succession and land use changes in a lake retreat area (Main Ethiopian Rift Valley). - Journal of Arid Environments 91: 53-60.

[34] Tian, L. (2015): Land use dynamics driven by rural industrialization and land finance in the peri-urban areas of China:"The examples of Jiangyin and Shunde". - Land Use Policy 45: $117-127$. 
[35] Turner, B.L., Moss, R.H., Skole, D. (1993): Relating land use and global land-cover change: a proposal for an IGBP-HDP core project. A report from the IGBP/HDP Working Group on Land-Use/Land-Cover Change. - Global Change Report (Sweden)

[36] Wang, Z., Huang, N., Luo, L., Li, X., Ren, C., Song, K., Chen, J.M. (2011): Shrinkage and fragmentation of marshes in the West Songnen Plain, China, from 1954 to 2008 and its possible causes. - International Journal of Applied Earth Observation and Geoinformation 13: 477-486.

[37] Wei, Y.D., Ye, X. (2009): Beyond convergence: space, scale, and regional inequality in China. - Tijdschrift voor economische en sociale geografie 100: 59-80.

[38] Wu, K.-y., Ye, X.-y., Qi, Z.-f., Zhang, H. (2013): Impacts of land use/land cover change and socioeconomic development on regional ecosystem services: The case of fastgrowing Hangzhou metropolitan area, China. - Cities 31: 276-284.

[39] Xian, G., Crane, M. (2005): Assessments of urban growth in the Tampa Bay watershed using remote sensing data. - Remote sensing of Environment 97: 203-215.

[40] Xie, Y., Batty, M., Zhao, K. (2007): Simulating emergent urban form using agent-based modeling: Desakota in the Suzhou-Wuxian region in China. - Annals of the Association of American Geographers 97: 477-495.

[41] $\mathrm{Xu}, \mathrm{W}$. (2004): The changing dynamics of land-use change in rural China: a case study of Yuhang, Zhejiang Province. - Environment and Planning A 36: 1595-1615.

[42] Yirsaw, E., Wu, W., Temesgen, H., Bekele, B. (2016): Effect of temporal land use/land cover changes on ecosystem services value in coastal area of China: The case of Su-XiChang region. - Applied Ecology and Environmental Research 14: 409-422.

[43] Yuan, H., Zhang, R. (2010): Changes in wetland landscape patterns on Yinchuan Plain, China. - International Journal of Sustainable Development \& World Ecology 17: 236243.

[44] Zhou, X., Chen, L., Xiang, W. (2014): Quantitative analysis of the built-up area expansion in Su-Xi-Chang region, China. - Ying yong sheng tai xue bao= The journal of applied ecology/Zhongguo sheng tai xue xue hui, Zhongguo ke xue yuan Shenyang ying yong sheng tai yan jiu suo zhu ban 25: 1422-1430.

\section{APPENDIX}

Appendix A. The various annual series of socioeconomic data of the Su-Xi-Chang region over the past 30 years used for this study

\begin{tabular}{llllllll}
\hline Year & $\begin{array}{l}\text { Population } \\
\left(\times 10^{3}\right)\end{array}$ & $\begin{array}{l}\text { Ind. Output Agri. Pro } \\
\left(10^{9} \mathrm{CNY}\right)\end{array}$ & $\begin{array}{l}\text { Aqu. Pro } \\
\left(\times 10^{5} \text { ton }\right)\end{array}$ & $\begin{array}{l}\text { GDP } \\
\left(\times 10^{6} \mathrm{CNY}\right)\end{array}$ & $\begin{array}{l}\text { Agri. Land } \\
\left(\times 10^{3} \text { ha }\right)\end{array}$ & $\begin{array}{l}\text { Cons. Land } \\
\left(\times 10^{2} \text { ha }\right)\end{array}$ \\
\hline 1980 & 1191.44 & 210 & 540.39 & 120.66 & 9.9 & 781.36 & 80.9 \\
1981 & 1204.55 & 230 & 487.42 & 125.586 & 10.61 & 779.85 & 80.5 \\
1982 & 1217.34 & 240 & 610.62 & 152.132 & 11.44 & 777.6 & 90.6 \\
1983 & 1222.89 & 280 & 604.22 & 151.164 & 12.85 & 776.88 & 96 \\
1984 & 1225.95 & 360 & 676.13 & 185.776 & 16.61 & 772.91 & 99.7 \\
1985 & 1233.93 & 510 & 538.77 & 231.141 & 22.14 & 765.55 & 105.1 \\
1986 & 1245.57 & 600 & 602.55 & 278.718 & 15.42 & 760.86 & 108.6 \\
1987 & 1260.22 & 750 & 565.21 & 303.477 & 29.71 & 757.58 & 111.9 \\
1988 & 1275.2 & 990 & 581.32 & 318.259 & 38.1 & 753.8 & 117 \\
\hline
\end{tabular}




\begin{tabular}{llllllll}
\hline 1989 & 1290.68 & 1110 & 570.34 & 322.999 & 40.86 & 752.77 & 120.5 \\
1990 & 1303.58 & 1230 & 601.95 & 337.012 & 45.75 & 751.26 & 124.2 \\
1991 & 1307.97 & 1330 & 576.96 & 324.575 & 52.21 & 750.16 & 137.9 \\
1992 & 1312.36 & 1440 & 551.97 & 312.139 & 80.81 & 749.06 & 154.1 \\
1993 & 1319.36 & 2410 & 591.95 & 348.315 & 119.02 & 737.88 & 173.2 \\
1994 & 1325.14 & 3570 & 567.72 & 372.112 & 164.04 & 729.06 & 180.4 \\
1995 & 1331.19 & 4740 & 552.64 & 412.938 & 202.85 & 720.83 & 188.5 \\
1996 & 1335.75 & 4720 & 578.81 & 452.861 & 229.51 & 712.54 & 201.8 \\
1997 & 1342.48 & 4870 & 603.88 & 464.161 & 255.05 & 691.36 & 207.8 \\
1998 & 1346.51 & 5010 & 608.56 & 476.479 & 279.29 & 688.08 & 215.5 \\
1999 & 1348.31 & 5460 & 542.7 & 501.561 & 301.77 & 685.19 & 222.1 \\
2000 & 1349.34 & 6070 & 525.57 & 521.389 & 331.79 & 684.36 & 231.3 \\
2001 & 1354.26 & 7090 & 457.19 & 558.672 & 376.18 & 681.59 & 330.9 \\
2002 & 1357.95 & 7750 & 391.9 & 577.017 & 437.51 & 673.68 & 378.1 \\
2003 & 1365.68 & 9490 & 365.51 & 588.776 & 553.64 & 652.28 & 416.4 \\
2004 & 1379.73 & 12,520 & 288.01 & 575.635 & 680.28 & 638.65 & 454.6 \\
2005 & 1395.01 & 17,380 & 305.06 & 553.112 & 825.52 & 587.86 & 487.5 \\
2006 & 1411.78 & 21,600 & 283.81 & 567.64 & 979.66 & 575.32 & 507.1 \\
2007 & 1428.55 & 27,230 & 307.16 & 562.868 & 1164.33 & 546.83 & 531 \\
2008 & 1443.55 & 33,960 & 261.91 & 550.901 & 1380.5 & 536.62 & 633.3 \\
2009 & 1452.69 & 37,590 & 306.51 & 557.026 & 1525.19 & 531.74 & 661 \\
2010 & 1458.76 & 40,530 & 307.63 & 535.986 & 1806.71 & 513.35 & 696.9 \\
\hline
\end{tabular}

NB: Ind. output $=$ Industrial output value; Agri. Pro $=$ Agricultural production; Aqu.pro $=$ Aquatic products; Agri. Land $=$ Agricultural land; Cons. Land $=$ Construction land (in this particular case it stands for residential area).

(Sources; Statistical year books and different surveys deployed in different time by the governmental offices of the region).

Appendix B. Landscape metrics selected for this study and their description

\begin{tabular}{llll}
\hline Acronym & Name (units) & Description & Justification \\
\hline NP & Number of patches & Total number of patches in the landscape & Fragmentation \\
PD & $\begin{array}{l}\text { Patch density (per } \\
\text { 100 ha) }\end{array}$ & Number of patches per unit area & Fragmentation \\
LSI & $\begin{array}{l}\text { Landscape shape } \\
\text { index }\end{array}$ & $\begin{array}{l}\text { The landscape boundary and total edge } \\
\text { within the landscape divided by the total } \\
\text { area, adjusted by a constant for a square } \\
\text { standard }\end{array}$ & Aggregation \\
& & & \\
& &
\end{tabular}




\begin{tabular}{|c|c|c|c|}
\hline LPI & $\begin{array}{l}\text { Largest patch index } \\
(\%)\end{array}$ & $\begin{array}{l}\text { Area of the largest patch in each class, } \\
\text { represents percent of the total landscape area }\end{array}$ & Dominance \\
\hline SHDI & $\begin{array}{l}\text { Shannon's diversity } \\
\text { index }\end{array}$ & $\begin{array}{l}\text { SHDI equals minus the sum, measure of } \\
\text { diversity. Approaches } 0 \text { when there is no } \\
\text { diversity, increases with number of patch } \\
\text { types. }\end{array}$ & Diversity \\
\hline IJI & $\begin{array}{l}\text { Interspersion and } \\
\text { juxtaposition index } \\
(\%)\end{array}$ & $\begin{array}{l}\text { Intermixing of patches of different types, } \\
\text { based on patch adjacencies. Increases to } 100 \\
\text { as the patch type becomes increasingly } \\
\text { interspersed with other patch type. }\end{array}$ & Fragmentation \\
\hline CONTAG & $\begin{array}{l}0<\text { CONTAG } \leq 100 \\
\text { Contagion index }(\%)\end{array}$ & $\begin{array}{l}\text { Approaches } 0 \text { when the patch types are } \\
\text { maximally disaggregated and interspersed. } \\
\text { Approaches } 100 \text { when the landscape consists } \\
\text { of a single patch. }\end{array}$ & Fragmentation \\
\hline AWMPFD & $\begin{array}{l}\text { Area-weighted mean } \\
\text { patch fractal } \\
\text { dimension }\end{array}$ & $\begin{array}{l}\text { Shape complexity weighted by the area of } \\
\text { patches }\end{array}$ & Fragmentation \\
\hline
\end{tabular}

Adapted from McGarigal et al. (2002). 